Expl Cell Biol. 1987;55:I-VI

\title{
Contents, Vol. 55, 1987
}

\section{Experimental Cell Biology}

International Journal of Basic Pathology, Neoplasia, Differentiation, Immunology and

Heterotransplantation

Founded 1938 as 'Schweizerische Zeitschrift fur allgemeine Pathologie und Bakteriologie' by A. v. Albertini, A. Grumbach and H. Mooser, continued as 'Pathologia et Microbiologia'

Editors

\section{Pathology}

J.R. Rüttner, Zurich Neoplasia, Differentiation

G.V. Sherbet, Newcastle upon Tyne Immunology

H. Ramseier, Zurich Heterotransplantation

L. Helson, Wilmington, Del.

Co-Editors

Pathology

R. Hess, Berne M. Kyogoku, Sendai M.A. Spycher, Zurich P. Vassalli, Geneva G. Zbinden, Zurich

Neoplasia

R.C. Coombes, Sutton

D. Glaves Rapp, Buffalo, N.Y.

I.R. Hart, London

M.S. Lakshmi, Newcastle upon Tyne L. Milas, Houston, Tex. G.L. Nicolson, Houston, Tex. G. Poste, Philadelphia, Pa. V. Schirrmacher, Heidelberg

E. Sidebottom, Oxford

Differentiation

B.M. Carlson, Ann Arbor, Mich. G.M.W. Cook, Cambridge U. Drews, Tubingen M. Feldman, Rehovot D.R. Garrod, Southampton

C. Graham, Oxford

J.R. Harris, Brentwood, Essex

PA. Riley, London

Immunology

H. Binz, Zurich

H. Hengartner, Zurich

J. Sprent, Philadelphia, Pa.

E. Wecker, Würzburg

H. Wigzell, Stockholm

R.M. Zinkernagel, Zurich

Heterotransplantation

B.C. Giovanella, Houston, Tex.

D.P. Houchens, Columbus, Ohio

I. Lefkovits, Basel 
T. Nomura, Kanagawa

N.D. Reed, Bozeman, Mont.

J. Rygaard, Copenhagen

S. Shin, Bronx, N.Y.

B.C.M. Sordat, Lausanne

Contents Vol. 55,1987

No. 1 The Endothelium of the High Endothelial Venule: A Specialized Endothelium with Unique Properties

Kraal, G.; Duijvestijn, A.M.; Hendriks, H.H 1

Hypothesis: Persistent Expression of Fetal Phenotypic Characteristics by Fibroblasts Is

Associated with an Increased Susceptibility to Neoplastic Disease

Schor, S.L.; Schor, A.M.; Howell, A.; Crowther, D 11

Alterations of MCF-7 Human Breast Cancer Cell after Prostaglandins PGAi and PGF2 $\alpha$

Treatment

Shahabi, N.A.; Chegini, N.; Wittliff, J.L 18

Transglutaminase Activity and Embryonal Carcinoma Cell Differentiation

Uhl, L.; Schindler, J 28

Alkaline Phosphatase Expression in Human Chorionic Villi

Novelli, G.; Mannello, F.; Cosmi, E.V.; Biagioni, S.; Dallapiccola, B 34

Guanine Salvage by Organ Cultures of Mouse Tooth Germs

Dye, F.J $\quad 42$

Protein Synthesis in Heterotopically Transplanted Rat Hearts

Currie, R.W.; Sharma, V.K.; Stepkowski, S.M.; Payee, R.F 46

No. 2 Morphometric Analysis of Collagen Fibrils in Idiopathic Carpal Tunnel Syndrome

Stransky, G.; Weis, S.; Neumüller, J.; Hakimzadeh, A.; Firneis, F.; Ammer, K.; Partsch,

G.; Eberl, R 57

Systemic Anaphylaxis in Mast-Cell-Deficient Mice of W/Wv and Sl/Sld Genotypes

Ha, T.-Y.; Reed, N.D 63

Chromosomal Aberrations in Early Stages of Development of Methotrexate Resistance in

HeLa Cells

Delinassios, J.G.; Talieri, MJ 69

Influence of Testicular Secretions on Differentiation in the Rat Epididymis: Ultrastructural

Studies after Castration, Efferent Duct Ligation and Cryptorchidism

Delongeas, J.-L.; Gelly, J.-L.; Leheup, B.; Grignon, G 74

Synergistic Action of Recombinant-Derived Murine Interleukin-1 on the Augmentation of

Colony Stimulating Activity on Murine Granulocyte-Macrophage Hematopoietic Stem

Cells in vitro

Gallicchio, V.S.; Watts, T.D.; DellaPuca, R 83

Effect of Dimethylsulfoxide and Hexamethylene Bisacetamide on the JOK-1 Hairy Cell

Leukemia Derived Cell Line Propagated in the Nude Mouse

Hooper, W.C.; Barth, R.F.; Houchens, D.P.; Nines, R 93

Vascularization of Normal Human Thyroid Tissue Transplanted to Nude Mice

Mölne, J.; Jörtsö, E.; Smeds, S.; Ericson, L.E 104

Book Review 115

Announcements 116

Contents 
III

No. 3 Characterization and Expression Kinetics of an Endothelial Cell Activation Antigen Present in vivo Only in Acute Inflammatory Tissues (with 1 color plate)

Goerdt, S.; Zwadlo, G.; Schlegel, R.; Hagemeier, H.-H.; Sorg, C 117

Activity and Function of Hybrid Ribonuclease in Cells of Acute and Chronic Myelogenous Leukemia

Papaphilis, A.D.; Kamper, E.F.; Pangalis, G.A.; Grammenou, S.; Kattamis, C 127

Interaction of Retinoids and Tamoxifen on the Inhibition of Human Mammary Carcinoma

Cell Proliferation

Fontana, J.A 136

Autoneuralization in the Amphibian Ectoderm - A Species-Specific and Stage-Specific

Phenomenon

Mattsson, M.-O.; Nakatsuji, N.; Løvtrup, S 145

Initiation of Primary Cell Cultures from Human Intracranial Tumors on Extracellular

Matrix from Bovine Corneal Endothelial Cells

Westphal, M.; Hansel, M.; Brunken, M.; König, A.; Köppen, J.A.; Herrmann, H.-D. . 152

Polyadenylate Polymerase Activity in Stationary and Growing Cell Cultures

Kazazoglou, T.; Tsiapalis, CM.; Havredaki, M 164

No. 4 Transfer of Granulomatous Inflammation with Nonviable Preparations of Schistosome Granulomas in Naive Mice

Okamoto, M.; Epstein, W.L.; Suya, H.; Kanazawa, K.; Fukuyama, K 173

Morphometric Analysis of Collagen Fibrils in Idiopathic Carpal Tunnel Syndrome: Part 2

Weis, S.; Stransky, G.; Dimitrov, L.; Wenger, E.; Neumüller, J.; Hakimzadeh, A.; Firneis,

F.; Partsch, G.; Eberl, R 179

Proliferation of Human Carcinoma Cells in Calcium-Deficient Culture Medium May

Depend on Autocrine Growth Factor(s)

Swierenga, S.H.H.; Auersperg, N 183

Differential Effects of Sodium Butyrate and Dimethylsulfoxide on Gamma-Glutamyl

Transpeptidase and Alkaline Phosphatase Activities in MCF-7 Breast Cancer Cells

Wasserman, L.; Nordenberg, J.; Beery, E.; Deutsch, A.A.; Novogrodsky, A 189

Isolation and Morphologic Characterization of Human Ovarian Carcinoma Cell Clusters

Present in Effusions

Allen, H.J.; Porter, C; Gamarra, M.; Piver, M.S.; Johnson, E.A.Z 194

Plasma Membrane-Associated Cysteine Proteinases in Human and Animal Tumors

Sloane, B.F.; Rozhin, J.; Hatfield, J.S.; Crissman, J.D.; Honn, K.V 209

No. 5 Differences in Growth Factor Sensitivity between Primary and Transformed Murine Cell

Cultures Revealed by BrdU/Hoechst Flow Cytometry

Kubbies, M.; Hoehn, H.; Rabinovitch, P.S 225

Human Monoclonal Antibodies Derived from Pleural Effusion Lymphocytes of a Patient with Breast Carcinoma React with Human Breast Cancer-Associated Antigens and

Mouse Mammary Tumor Virus Polypeptides

Smorodinsky, N.I.; Argov, S.; Ghendles, Y.; Bakimer, R.; Krup, M.; Lupu, R.; Keydar, I.; Shoenfeld, Y 237

Methodology for Detection of Heterogeneity of Cell Locomotory Phenotypes in Three-

Dimensional Gels

Shields, E.D.; Noble, P.B 250 
IV

Contents

Effects of Urinary Extracts from Patients with Idiopathic Thrombocytopenic Purpura or Aplastic Anemia on Rodent Platelet Production and Megakaryocytopoiesis

Kuriya, S-L·, Kamamoto, T.; Murphy, M.J., Jr 257

Human Bone Marrow CFU-GM and BFU-E Localized by Light Scatter Cell Sorting

Atzpodien, J.; Gulati, S.C.; Kwon, J.H.; Wachter, M.; Fried, J.; Clarkson, B.D 265

Transition from Non-Muscle to Muscle Myosin Light Chains in Chick Embryo Devel

opment

Fascio, U.; De Bernardi, F 271

5-Azacytidine Inhibits Adipocytic Conversion of Human Skin Fibroblasts by Kirsten

Murine Sarcoma Virus and Dexamethasone

Kopelovich, L 276

Fibroblasts from Persons Predisposed to Cancer Are Abnormally Resistant to 5-Azacyti-

dine-Induced Cytotoxicity

Kopelovich, L.; Fenyk, J 281

No. 6 Mophological Aspects of Interactions between Asbestos Fibers and Human Mesothelial Cell Cytoskeleton

Rüttner, J.R.; Lang, A.B.; Gut, D.R.; Wydler, M.U 285

A Monoclonal Antibody to a Novel Differentiation Antigen on Human Macrophages Asso ciated with the Down-Regulatory Phase of the Inflammatory Process

Zwadlo, G.; Voegeli, R.; Osthoff, K.S.; Sorg, C 295

Influence of Albumin on Granulocyte and Macrophage Colony-Forming Efficiency

Iizuka, Y.; Oshima, T.; Muphy, M.J., Jr 305

Contribution of the Extracellular Matrix to Growth Properties of Cells from a Preneoplastic

Outgrowth: Possible Role of Hyaluronic Acid

Elstad, C.A.; Hosick, H.L 313

Discrepancy between Flow Cytometric Analyses of CALLA Using Two Monoclonal Anti bodies

Fried, J.; Perez, A.G.; Shimazaki, C; Clarkson, B.D 322

Acknowledgments $\quad 331$

Announcement 332

Author Index $\quad 333$

Subject Index $\quad 335$

S. Karger $\cdot$ Medical and Scientific Publishers

Basel $\cdot$ München $\square$ Paris $\square$ London $\cdot$ New York $\cdot$ New Delhi $\cdot$ Singapore $\cdot$ Tokyo $\cdot$ Sydney

Drug Dosage All rights reserved.

The authors and the publisher have exerted every effort No part of this publication may be translated into other

to ensure that drug selection and dosage set forth in this languages, reproduced or utilized in

any form or by any

text are in accord with current recommendations and means, electronic or mechanical,

including photocopy-

practice at the time of publication. However, in view of ing, recording, microcopying, or by

any information stor-

ongoing research, changes in government regulations, age and retrieval system, without 
permission in writing

and the constant flow of information relating to drug from the publisher or, in the case of photocopying, direct

therapy and drug reactions, the reader is urged to check payment of a specified fee to the Copyright Clearance

the package insert for each drug for any change in indica- Center (see 'Information for Readers and Subscribers'),

tions and dosage and for added warnings and precau

tions. This is particularly important when the recom-

mended agent is a new and/or infrequently employed

(C) Copyright 1987 by

Basel (Switzerland)

drug. Printed in Switzerland by Thür AG Offsetdruck, Prattcln 